\title{
Controlled-release Fertilizer during Cutting Propagation Affects Growth and Tissue Nutrient Concentrations of Rooted Cuttings of Annual Bedding Plants
}

\author{
Christopher J. Currey ${ }^{1}$ and Roberto G. Lopez ${ }^{2,3}$ \\ Department of Horticulture and Landscape Architecture, Purdue University, \\ West Lafayette, IN 47907-2010
}

Additional index words. liners, macronutrient, micronutrient, vegetative, water-soluble fertilizer

Abstract. Our objectives were to quantify the effects of controlled-release fertilizer (CRF) on the growth, morphology, and tissue nutrient concentration of annual bedding plants during propagation. Unrooted cuttings of Angelonia angustifolia 'AngelFace White' and 'Sundancer Pink', Impatiens hawkeri 'Celebrette Apricot' and 'Celebrette Rose Hot', Nemesia fruticans 'Bluebird' and 'Raspberry Sachet', Pelargonium $\times$ hortorum 'Savannah Red', and Petunia $\times$ hybrida 'Cascadia Marshmallow Pink' and 'Suncatcher Yellow' were received from a commercial propagator. Cuttings were immediately stuck individually in cells containing soilless substrate supplemented with 0, 3, 6, 12, or $24 \mathrm{~g} \cdot \mathrm{L}^{-1}$ CRF (Osmocote Plus 15-3.9-10 3-4 month) and placed under clear mist water or cuttings were stuck in substrate containing no CRF and fertilized with water-soluble fertilizer beginning immediately after placing cuttings into propagation. Shoot dry mass of cuttings grown in substrates containing up to 12 or $24 \mathrm{~g} \cdot \mathrm{L}^{-1}$ CRF increased by up to $150 \%$ for some taxa compared with unfertilized cuttings. Incorporating CRFs into propagation substrates increased the concentration of nitrogen $(\mathrm{N})$, phosphorus $(\mathrm{P})$, and potassium $(\mathrm{K})$ in tissues by up to $103 \%, 42 \%$, and $137 \%$, respectively, compared with unfertilized cuttings. Additionally, tissue nutrient concentrations for cuttings fertilized with $6 \mathrm{~g} \cdot \mathrm{L}^{-1} \mathrm{CRF}$ or greater were similar to cuttings receiving water-soluble fertilizer (WSF). When the impact of CRF on growth and nutrient concentrations are taken together, our results indicate that CRF is a fertilization application technology that holds promise for use during propagation of herbaceous stem-tip cuttings.

Young plants propagated from seed (plugs) or stem-tip cuttings (liners) are commonly used in herbaceous ornamental annual bedding plant production and propagative material for this use is currently valued at over $\$ 159$ million (U.S. Department of Agriculture, 2012). Unrooted cuttings received in the United States generally have tissue nutrient concentrations

Received for publication 2 May 2013. Accepted for publication 4 Dec. 2013.

We gratefully acknowledge Tyler Mason, Rob Eddy, and Dan Hahn for greenhouse assistance, funding from growers providing support for Purdue University floriculture research, and support from the Purdue Agricultural Experiment Station. We thank Ball Horticultural Co. for plant material, Conrad Fafard, Inc. for substrate, Everris for the controlled-release fertilizer and tissue analyses, Ludvig Svensson for shadecloth, J.R. Peters, Inc. for water-soluble fertilizer, and the Indiana Flower Growers Association and Fred. C. Gloeckner Foundation, Inc. for support.

The use of trade names in this publication does not imply endorsement by Purdue University of products named nor criticism of similar ones not mentioned. ${ }^{1}$ Former Graduate Student.

${ }^{2}$ Associate Professor and Extension Specialist.

${ }^{3}$ To whom reprint requests should be addressed; e-mail rglopez@purdue.edu. within published, recommended ranges on receipt (Gibson et al., 2007; Santos et al., 2011a). However, during the propagation phase of herbaceous stem-tip cuttings, the concentration declines resulting from leaching of nutrients and the dilution effect, whereas mineral nutrient content in tissues decline from leaching (Blazich, 1988; Svenson and Davies, 1995). As a result, the mineral nutrient content and concentrations of cuttings must be replenished during propagation, and this is frequently accomplished by providing mineral nutrients through application of WSF.

A survey of greenhouse producers of liners conducted by Santos et al. (2008) reported large variation among fertilization application practices in propagation facilities. It is common practice for producers to begin providing WSF during the first week of cutting propagation, either through mist application or substrate fertigation, increasing fertilizer application concentration as propagation proceeds. As propagation proceeds from callusing (Stage 2) to toning (Stage 4), fertilizer application concentration increases from 0 to $200 \mathrm{mg} \cdot \mathrm{L}^{-1}$ of $\mathrm{N}$ applied through mist or 0 to $400 \mathrm{mg} \cdot \mathrm{L}^{-1}$ applied with a hose. Santos et al. (2008) also reported that up to $46.9 \mathrm{~L}$ of leachate $/ \mathrm{m}^{2}$ of bench space was leached from the root zone during a typical 4-week production cycle for rooted cuttings. Furthermore, $23 \%, 34 \%$, and $28 \%$ of $\mathrm{N}, \mathrm{P}$, and $\mathrm{K}$ applied, respectively, were leached during propagation in eight different commercial greenhouses (Santos et al., 2008).

CRFs are polymer-enclosed fertilizers that release nutrients based on the temperature and moisture status of the substrate (Nelson, 2012; Sonneveld and Voogt, 2009). Additionally, CRFs have several distinct advantages compared with traditional WSF, including the potential to reduce levels of mineral nutrient leaching. Greenhouse producers of highquality rooted cuttings aim to provide a sufficient supply of mineral nutrients and an environment conducive to nutrient uptake and assimilation to minimize production time. However, it is also of interest to limit excessive nutrient application and leaching in the propagation environment to minimize loss of fertilizer and runoff. Therefore, the same advantages that CRFs may confer for containerized crop production are also desirable in cutting propagation. Our objectives in this study were to quantify the effectiveness of CRFs during propagation of herbaceous stemtip cuttings compared with traditional WSF.

\section{Materials and Methods}

Expt. 1. On 18 Jan. 2012, $\approx 100$ cuttings of Angelonia angustifolia 'AngelFace White' and 'Sundancer Pink', Nemesia fruticans 'Bluebird' and 'Raspberry Sachet', and Petunia $\times$ hybrida 'Cascadia Marshmallow Pink' were received at Purdue University, West Lafayette, IN (lat. $40^{\circ} \mathrm{N}$ ). Cuttings were placed in 105-cell propagation trays (28-mL individual cell volume; T.O. Plastics, Inc., Clearwater, MN) filled with a propagation substrate composed of $(\mathrm{v} / \mathrm{v})$ three parts soilless substrate (Fafard 1P; Conrad Fafard, Inc., Agawam, MA) and one part coarse perlite (Strong-Lite Coarse Perlite; Sun Gro Horticulture, Bellevue, WA) containing 0, 3, 6,12 , or $24 \mathrm{~g} \cdot \mathrm{L}^{-1} \mathrm{CRF}$ (Osmocote Plus $15 \mathrm{~N}$ 3.9P-10K 3-4 month; Everris NA, Inc., Dublin, $\mathrm{OH})$. Cuttings were sprayed to runoff with a solution containing $300 \mathrm{mg} \cdot \mathrm{L}^{-1}$ nonionic surfactant (CapSil; Aquatrols, Paulsboro, NJ) so that water would not accumulate on the plant foliage surface.

Cuttings in propagation substrate containing 0 to $24 \mathrm{~g} \cdot \mathrm{L}^{-1} \mathrm{CRF}$ then were misted with tap water supplemented with $93 \%$ sulfuric acid (Brenntag, Reading, PA) at $0.08 \mathrm{~mL} \cdot \mathrm{L}^{-1}$ to reduce total alkalinity concentration to $100 \mathrm{mg} \cdot \mathrm{L}^{-1}$ and to maintain a water $\mathrm{pH}$ to a range of 5.8 to 6.2. An additional group of cuttings was placed in substrate containing no CRF and were misted with acidified tap water supplemented with a complete WSF (Jack's LX $16 \mathrm{~N}-0.9 \mathrm{P}-12.3 \mathrm{~K}$ Plug Formula for High Alkalinity Water; J.R. Peters, Inc., Allentown, PA) and micronutrient supplement (Compound 111; Everris NA, Inc.) providing (in $\mathrm{mg} \cdot \mathrm{L}^{-1}$ ) with each misting event: $60 \mathrm{~N}, 6 \mathrm{P}, 47 \mathrm{~K}$, 11 calcium $(\mathrm{Ca}), 6$ magnesium $(\mathrm{Mg}), 0.3$ boron $(\mathrm{B}), 0.1$ copper $(\mathrm{Cu}), 1.5$ iron $(\mathrm{Fe})$, 


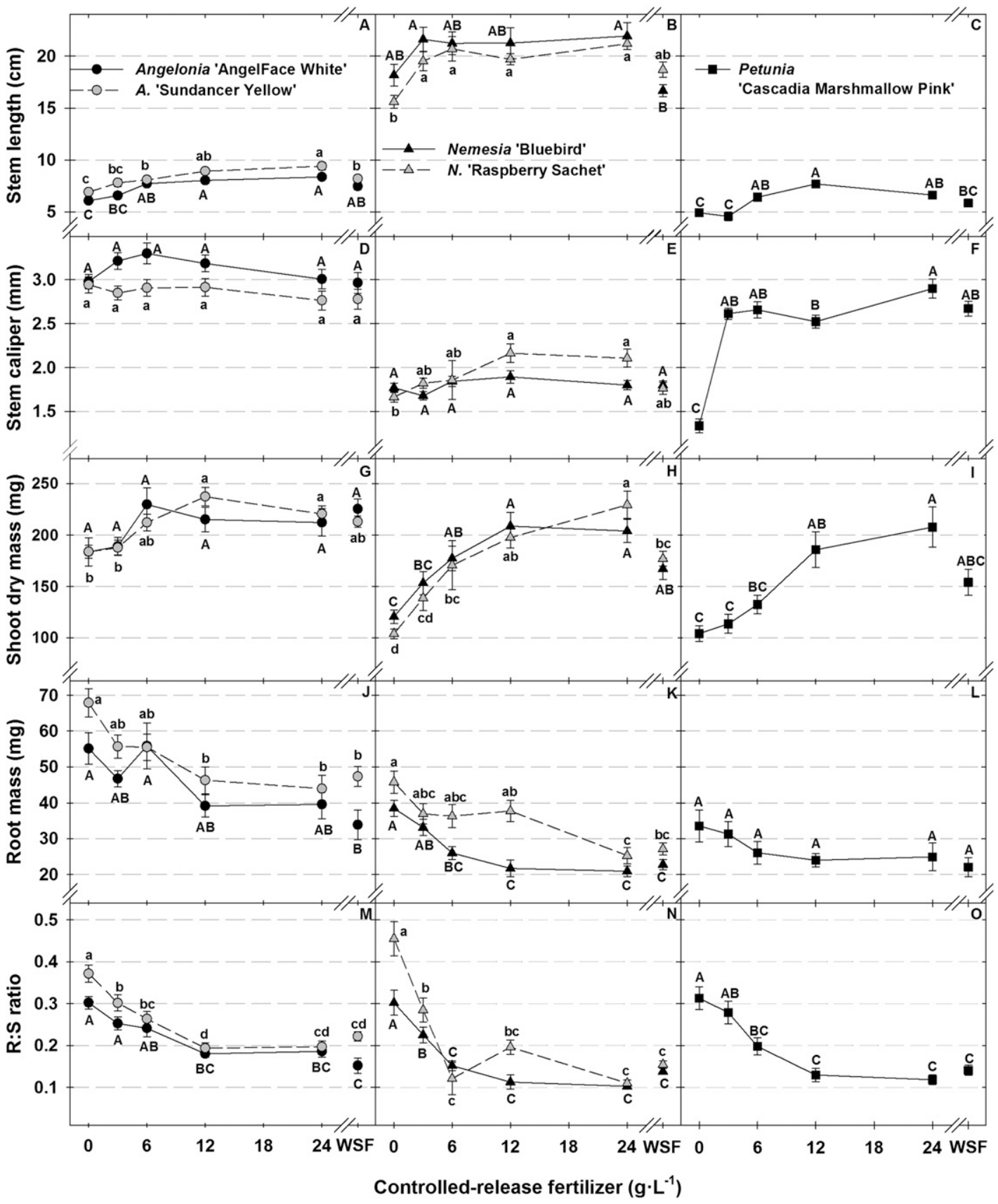

Fig. 1. (A-O) Stem length, stem caliper, shoot and root dry mass, and root:shoot dry mass ratio of Angelonia 'AngelFace White' and 'Sundancer Pink', Nemesia 'Bluebird and Raspberry Sachet', and Petunia 'Cascadia Marshmallow pink' cuttings $28 \mathrm{~d}$ after inserting cuttings into substrate containing 0, 3, 6, 12, or 24 g controlled-release fertilizer (CRF) per liter or provided water-soluble fertilizer (WSF) during propagation. Each symbol represents the mean of 14 cuttings, and error bars represent sES of the mean. Different letters are significantly different by Tukey's honestly significant difference (HSD) test at $P \leq 0.05$ within each cultivar.

0.4 manganese (Mn), 0.09 molybdenum (Mo), and 0.21 zinc $(\mathrm{Zn})$.

Ten days after the placement of cuttings in propagation treatments, the use of mist was discontinued. Cuttings grown in substrates containing CRFs were irrigated with unfertilized water, whereas cuttings grown with WSF were hand-irrigated with acidified water supplemented with a combination of two WSFs $(3: 1$ mixture of $15 \mathrm{~N}-$ $2.2 \mathrm{P}-12.5 \mathrm{~K}$ and $21 \mathrm{~N}-2.2 \mathrm{P}-16.6 \mathrm{~K}$, respectively; Everris NA, Inc.) to provide the following (in $\mathrm{mg} \cdot \mathrm{L}^{-1}$ ): $200 \mathrm{~N}, 26 \mathrm{P}, 163 \mathrm{~K}, 50 \mathrm{Ca}$, $20 \mathrm{Mg}, 1.0 \mathrm{Fe}, 0.5 \mathrm{Mn}$ and $\mathrm{Zn}, 0.2 \mathrm{Cu}$ and $\mathrm{B}$, and $0.1 \mathrm{Mo}$.
All cuttings were placed in a glass-glazed greenhouse under a 16-h photoperiod with air and substrate temperature set points of $23 \pm$ $1{ }^{\circ} \mathrm{C}$ and a daily light integral maintained at $\approx 5 \mathrm{~mol} \cdot \mathrm{m}^{-2} \cdot \mathrm{d}^{-1}$ for callusing and $\approx 10$ to $12 \mathrm{~mol} \cdot \mathrm{m}^{-2} \cdot \mathrm{d}^{-1}$ for rooting. Resistance-based sensors (External Temperature Sensor; Spectrum Technologies, Inc.) recorded air and substrate temperatures every $30 \mathrm{~s}$ and averages were logged every $15 \mathrm{~min}$ by a data logger (Watchdog 2800 Weather Station; Spectrum Technologies, Inc.). Two amplified quantum sensors (SQ-212; Apogee Instruments, Inc., Logan, UT) measured photosynthetic photon flux every $30 \mathrm{~s}$ under each lighting treatment, and the average of each sensor was logged every 15 min by a data logger (Watchdog 2800 Weather Station; Spectrum Technologies, Inc.).

Data were collected after $28 \mathrm{~d}$ of propagation. Cuttings were removed from propagation trays and substrate was gently rinsed off the roots. Stem caliper above the lowest leaf and stem length from the base of the cutting to the apical meristem were measured with a digital caliper (digiMax; Wiha, Schonach, Germany). Roots and leaves were excised from the stem and were dried separately in an oven at $70^{\circ} \mathrm{C}$ for $3 \mathrm{~d}$, after which shoot (SDM) and root dry mass (RDM) were recorded. 
Dried shoot tissue of samples for each 14cell propagation strip was combined for tissue analyses. Determination of Kjeldahl nitrogen for all tissue samples began with standard digestion in concentrated sulfuric acid at $360{ }^{\circ} \mathrm{C}$ for $\approx 1.5 \mathrm{~h}$ using a Tecator 40 block digestor. The resultant ammonium fraction was measured with a Lachat QuikChem 8500 flow-injection analyzer using a buffered salicylate-hypochlorite solution for color development. Determination of elemental species $(\mathrm{Ca}, \mathrm{Mg}, \mathrm{K}, \mathrm{P}, \mathrm{Mn}, \mathrm{Fe}, \mathrm{Zn}$, $\mathrm{Cu}, \mathrm{B}, \mathrm{S}, \mathrm{Mo}$ ) in all tissue samples began with an initial digestion in concentrated nitric acid at $90{ }^{\circ} \mathrm{C}$ followed by three small additions of $30 \%$ hydrogen peroxide with a total time for digestion being $\approx 1 \mathrm{~h}$. Digested samples were filtered and analyzed by inductively coupled plasma-optical emission spectroscopy (Perkin Elmer 4300 DV spectrometer) for those elements shown. There was insufficient tissue to measure shoot $\mathrm{N}$ concentrations of Petunia 'Suncatcher Yellow' cuttings fertilized with 0 or $3 \mathrm{~g} \cdot \mathrm{L}^{-1}$.

For each species, the experiment employed a completely randomized design with fertilizer (six levels) as treatments. There were two propagation strips (replications) with seven individual cuttings (samples) per species per treatment. Cuttings were randomly assigned to fertilizer treatments. Analyses of variance and mean separation by Tukey's honestly significant difference test at $P \leq 0.05$ were performed using SPSS 17.0 (IBM Corp., Armonk, NY).

Expt. 2. On 28 Feb. 2012, cuttings of Impatiens hawkeri 'Celebrette Apricot' and 'Celebrette Rose Hot', Petunia ×hybrida 'Suncatcher Yellow', and Pelargonium Xhortorum 'Savannah Red' were stuck and grown as described in Expt. 1. Data collection, calculation, and statistical analysis were performed as described in Expt. 1, except there were three propagation strips per species per treatment.

\section{Results}

Growth and morphology. The impact of fertilizer type on stem length and caliper compared with unfertilized cuttings was different among taxa (Figs. 1A-F and 2A-D). For example, $24 \mathrm{~g} \cdot \mathrm{L}^{-1} \mathrm{CRF}$ increased stem length of Impatiens 'Celebrette Apricot' and Petunia 'Suncatcher Yellow' by $25 \%(1.0 \mathrm{~cm})$ and $98 \%(4.2 \mathrm{~cm})$, respectively, compared with unfertilized cuttings. Alternatively, Angelonia 'Sundancer Pink' cuttings receiving WSF were $13 \%(1.2 \mathrm{~cm})$ shorter than those receiving $24 \mathrm{~g} \cdot \mathrm{L}^{-1} \mathrm{CRF}$. Stem length of Nemesia 'Bluebird' and Pelargonium was unaffected by fertilizers. Fertilizer did not affect stem caliper growth for two-thirds of the species in this study. However, stem caliper of Nemesia 'Raspberry Sachet' and Petunia 'Cascadia Marshmallow Pink' increased by up to $30 \%(0.5 \mathrm{~mm})$ and $117 \%$ $(1.6 \mathrm{~mm})$, respectively, in response to CRF, whereas WSF increased stem caliper of $\mathrm{Im}$ patiens 'Celebrette Apricot' by $33 \%$ (1.1 mm) compared with unfertilized cuttings.
The effect of fertilization on SDM and RDM of cuttings varied among taxa (Figs. $1 \mathrm{G}-\mathrm{O}$ and $2 \mathrm{E}-\mathrm{J})$. As CRF increased from 0 to 12 or 24 g. L ${ }^{-1}$, SDM increased by $29 \%$ (54 mg; Angelonia 'Sundancer Pink') to 121\% (125 mg; Nemesia 'Raspberry Sachet'), whereas WSF increased SDM by $39 \%$ (47 mg; Nemesia 'Bluebird') to 150\% (70 mg; Petunia 'Suncatcher Yellow) compared with unfertilized cuttings. The SDM of Angelonia

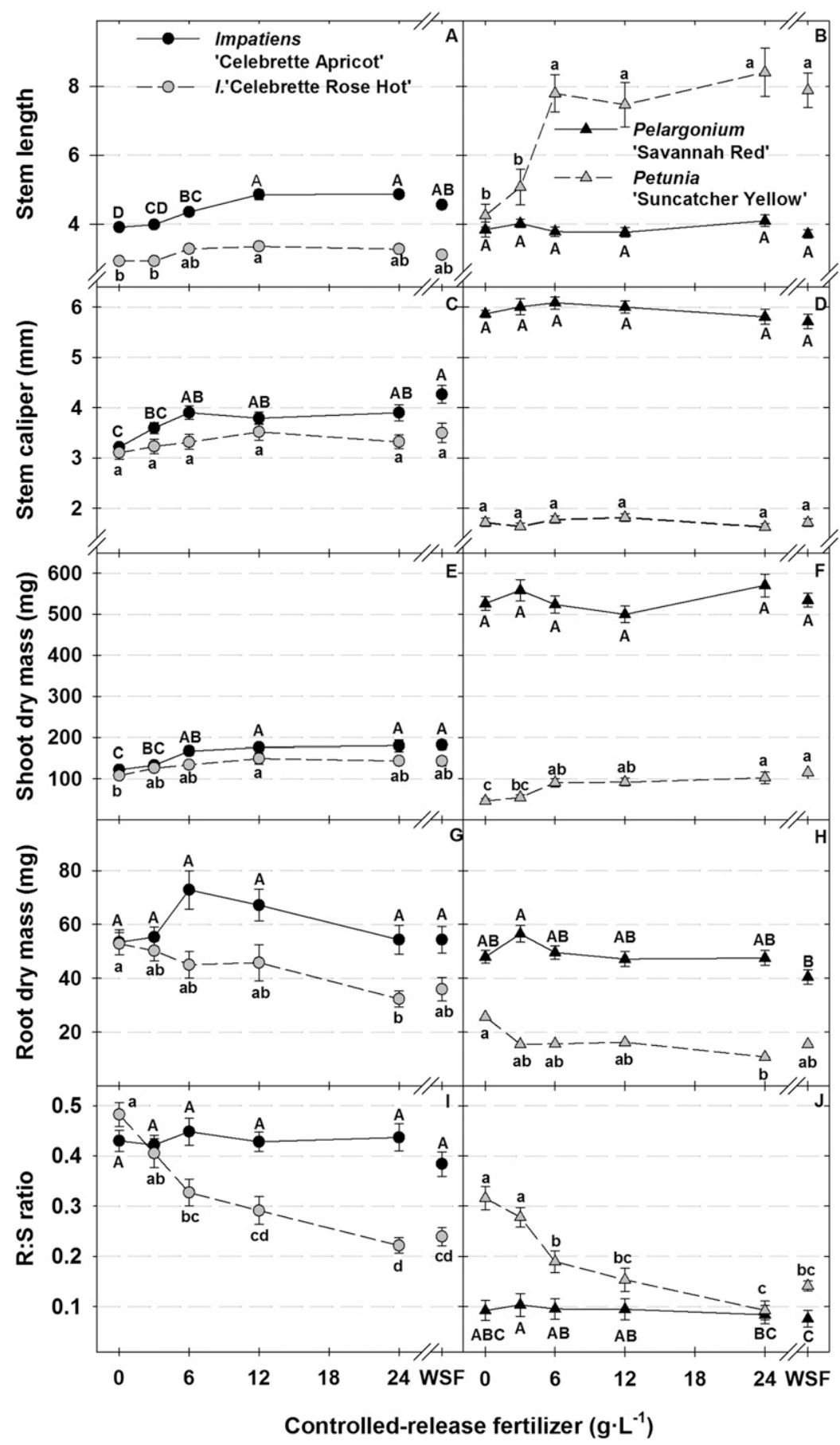

Fig. 2. (A-J) Stem length, stem caliper, shoot and root dry mass, and root:shoot dry mass ratio of Impatiens hawkeri 'Celebrette Apricot' and 'Celebrette Rose Hot', Pelargonium $\times$ hortorum 'Savannah Red', and Petunia $\times$ hybrida 'Suncatcher Yellow' $28 \mathrm{~d}$ after inserting cuttings into substrate containing $0,3,6,12$, or $24 \mathrm{~g}$ controlled-release fertilizer (CRF) per liter or provided water-soluble fertilizer (WSF) during propagation. Each symbol represents the mean of 21 cuttings, and error bars represent SES of the mean. Different letters are significantly different by Tukey's honestly significant difference (HSD) test at $P \leq$ 0.05 within each cultivar.
'AngelFace White' and Pelargonium was unaffected by fertilizers. The RDM of both Angelonia and Nemesia cultivars receiving WSF decreased by $30 \%$ (21 mg; Angelonia 'Sundancer Pink') to 41\% (19 mg; Nemesia 'Raspberry Sachet') compared with unfertilized cuttings. Similarly, RDM for Angelonia 'Sundancer Yellow' and Nemesia 'Bluebird' and 'Raspberry Sachet' decreased by $35 \%$ (24 mg), 46\% (18 mg), and 45\% (21 mg), 


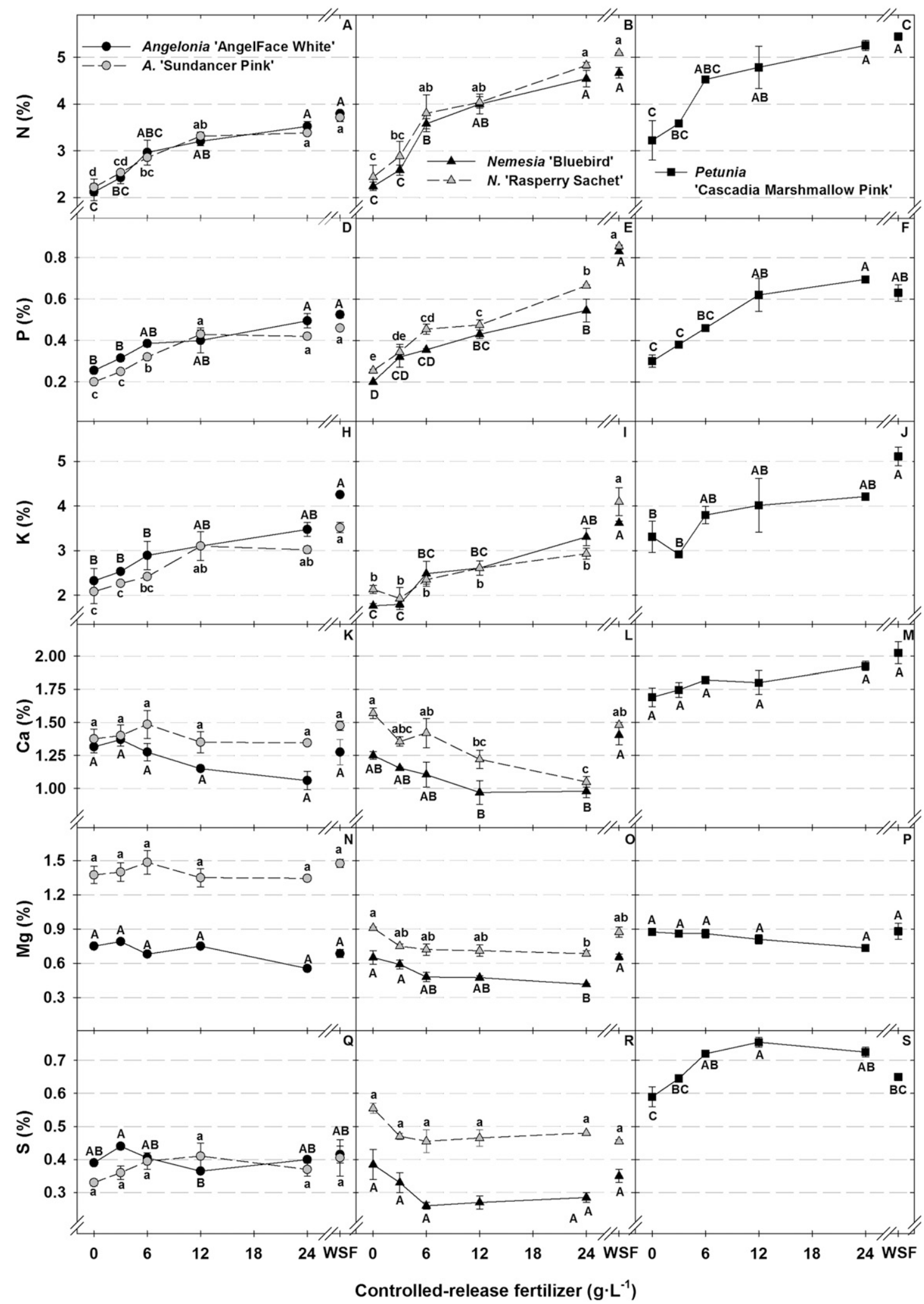

Fig. 3. (A-R) Tissue nitrogen (N), phosphorus (P), potassium (K), magnesium (Mg), calcium (Ca), and sulfur (S) concentrations (\%) of Angelonia 'AngelFace White' and 'Sundancer Pink' angelonia, Nemesia 'Bluebird and Raspberry Sachet', and Petunia 'Cascadia Marshmallow pink' shoot tissue $28 \mathrm{~d}$ after inserting cuttings into substrate containing $0,3,6,12$, or $24 \mathrm{~g}$ controlled-release fertilizer (CRF) per liter or provided water-soluble fertilizer (WSF) during propagation. Each symbol represents the mean of two 14-cell propagation strips, and error bars represent ses of the mean. Different letters are significantly different by Tukey's honestly significant difference (HSD) test at $P \leq 0.05$ within each cultivar.

respectively, as CRF increased from 0 to 24 $\mathrm{g} \cdot \mathrm{L}^{-1}$. Alternatively, RDM of both Impatiens and Petunia cultivars and Pelargonium were not significantly affected by fertilizer. Although the root:shoot (R:S) ratio of Impatiens 'Celebrette Apricot' and Pelargonium was unaffected or minimally affected by fertilizers, the R:S ratio of the other cultivars was reduced by $48 \%$ (0.18, Angelonia 'Sundancer Pink') to $76 \%$ (0.34, Nemesia Raspberry Sachet') for cuttings receiving CRF or WSF. 
Mineral nutrient concentrations. Both CRF and WSF increased nearly every primary macronutrient tissue concentration for each species (Figs. 3H-I and 4A-F). For example, cuttings propagated in substrate containing 24 g. $\mathrm{L}^{-1} \mathrm{CRF}$ had 52\% (1.17\%; Angelonia 'Sundancer Pink') to 103\% (2.3\%; Nemesia 'Bluebird') greater N, 42\% (0.14\%; Impatiens 'Celebrette Rose Hot') to $173 \%$ (0.35\%; Nemesia 'Bluebird') greater P, or $50 \%$ (1.16\%; Angelonia 'AngelFace White') to $124 \%(1.57 \%$; Pelargonium $) \mathrm{K}$, respectively, compared with unfertilized cuttings. Similarly, WSF increased N by $67 \%(1.5 \%$; Angelonia 'Sundancer Pink') to $111 \%$ (2.44\%; Impatiens 'Celebrette Rose Hot'), P by $97 \%$ $(0.30 \%$; Pelargonium $)$ to $315 \%(0.63 \%$; Nemesia 'Bluebird'), and K by 54\% (1.8\%; Petunia 'Cascadia Marshmallow Pink') to $132 \%$ (1.67\%; Pelargonium) compared with unfertilized cuttings. The $\mathrm{P}$ concentration of $\mathrm{Pe}$ tunia 'Suncatcher Yellow' tissue was not significantly affected by fertilizers.

Fertilization affected secondary macronutrient tissue concentrations of species differently (Fig. 3J-R and 4G-L). Compared with unfertilized cuttings, tissue $\mathrm{Ca}$ increased by $28 \%(0.27 \%)$ for Pelargonium cuttings fertilized with WSF only, whereas 12 or $24 \mathrm{~g} \cdot \mathrm{L}^{-1}$ CRF treatments had lower Ca by $27 \%(0.27 \%$ to $0.28 \%$ ) for Nemesia 'Bluebird'. Fertilizers had no significant effect on tissue $\mathrm{Ca}$ of the remaining species. Although tissue $\mathrm{Mg}$ for Pelargonium decreased by $17 \%$ to $21 \%$ $(0.07 \%$ to $0.09 \%)$ or $32 \%(0.13 \%)$ for cuttings fertilized with 12 to $24 \mathrm{~g} \cdot \mathrm{L}^{-1} \mathrm{CRF}$ or WSF, respectively, compared with unfertilized cuttings, $\mathrm{Mg}$ concentrations decreased by $36 \%(0.24 \%)$ and $25 \%(0.23 \%)$ for Nemesia 'Bluebird' and 'Raspberry Sorbet' fertilized with $24 \mathrm{~g} \cdot \mathrm{L}^{-1} \mathrm{CRF}$, respectively, and by $18 \%(0.16 \%)$ for Impatiens 'Celebrette Rose Hot' receiving WSF. Tissue $\mathrm{Mg}$ for the remaining species was unaffected by fertilizers. As CRF increased from 0 to $6 \mathrm{~g} \cdot \mathrm{L}^{-1}$ or greater, tissue sulfur (S) of Pelargonium and Petunia 'Cascadia Marshmallow Pink' increased by up to $40 \%(0.14 \%)$ and $23 \%$ $(0.14 \%)$, respectively. Alternatively, fertilizing Impatiens 'Celebrette Rose' and Petunia 'Suncatcher Yellow' cuttings with WSF reduced tissue $\mathrm{S}$ by $35 \%(0.30 \%)$ and $38 \%$ $(0.38 \%)$, respectively. Fertilizers did not affect tissue $\mathrm{S}$ of the remaining species. The irrigation water used in these experiments, both with and without fertilizer, was acidified with sulfuric acid to reduce alkalinity and $\mathrm{pH}$, likely providing cuttings with $\mathrm{S}$.

Fertilizing cuttings of Petunia 'Suncatcher Yellow', Angelonia 'Sundancer Pink', and Nemesia 'Bluebird' with 3,12 , or $24 \mathrm{~g} \cdot \mathrm{L}^{-1}$ $\mathrm{CRF}$, respectively, increased tissue $\mathrm{B}$ concentrations by $61 \%$ (40.4 ppm), 60\% (23.6 $\mathrm{ppm})$, or $83 \%$ (35.6 ppm), respectively, compared with unfertilized cuttings. Similarly, WSF increased tissue B concentrations of both Angelonia cultivars, Impatiens 'Celebrette Apricot', and Pelargonium by $34 \%$ (22.3 ppm, Impatiens 'Rose Apricot) to 55\% (21.5 ppm, Angelonia 'Sundancer Pink'). Tissue B of Impatiens 'Celebrette Rose

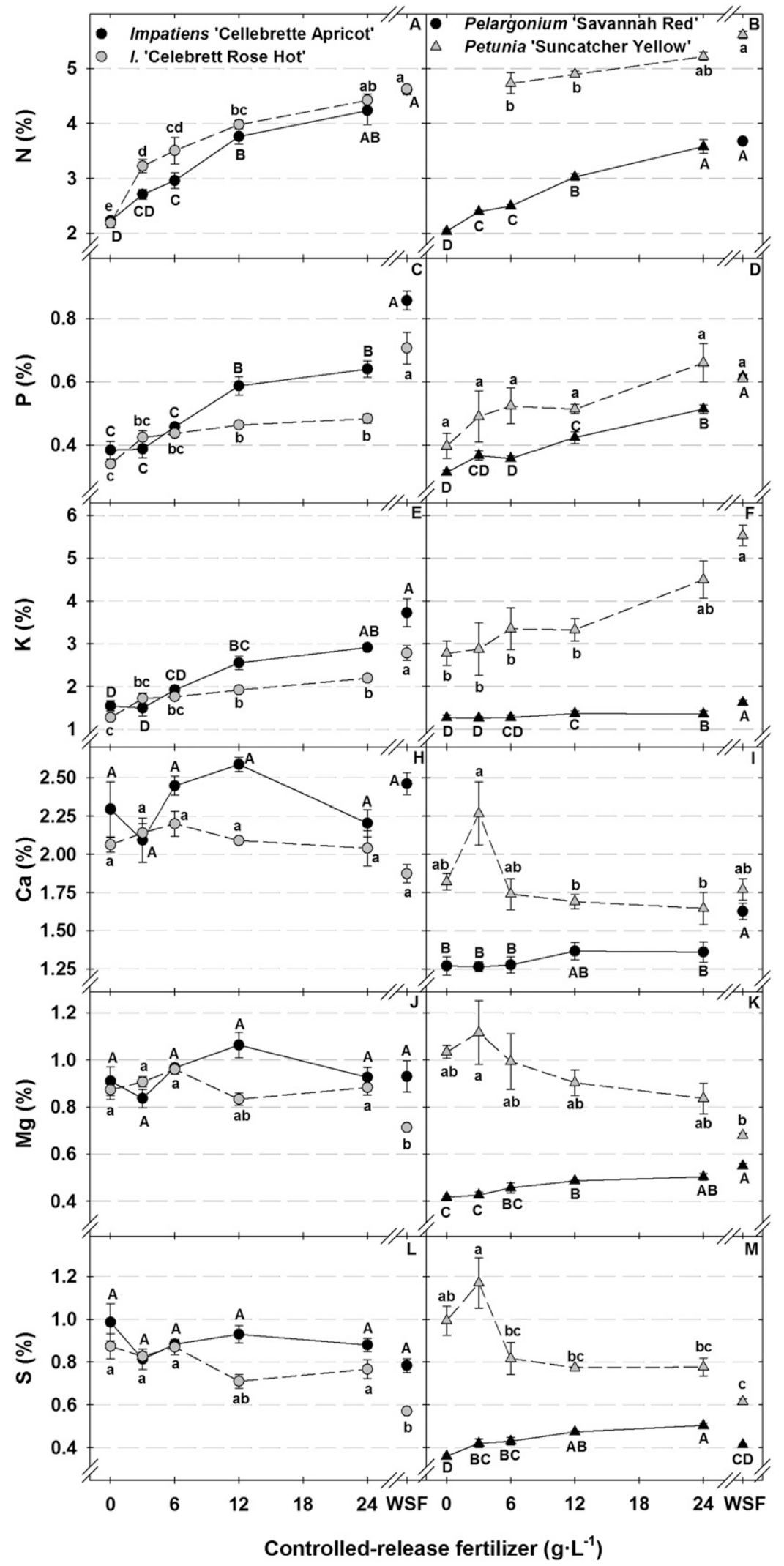

Fig. 4. (A-L) Tissue nitrogen $(\mathrm{N})$, phosphorus $(\mathrm{P})$, potassium $(\mathrm{K})$, magnesium $(\mathrm{Mg})$, calcium $(\mathrm{Ca})$, and sulfur (S) concentration (\%) of Impatiens hawkeri 'Celebrette Apricot' and 'Celebrette Rose Hot', Pelargonium $\times$ hortorum 'Savannah Red', and Petunia $\times$ hybrida 'Suncatcher Yellow' shoot tissue $28 \mathrm{~d}$ after inserting cuttings into substrate containing $0,3,6,12$, or $24 \mathrm{~g}$ controlled-release fertilizer (CRF) per liter or provided water-soluble fertilizer (WSF) during propagation. Each symbol represents the mean of three 14-cell propagation strips, and error bars represent SES of the mean. Different letters are significantly different by Tukey's honestly significant difference (HSD) test at $P \leq 0.05$ within each cultivar. 


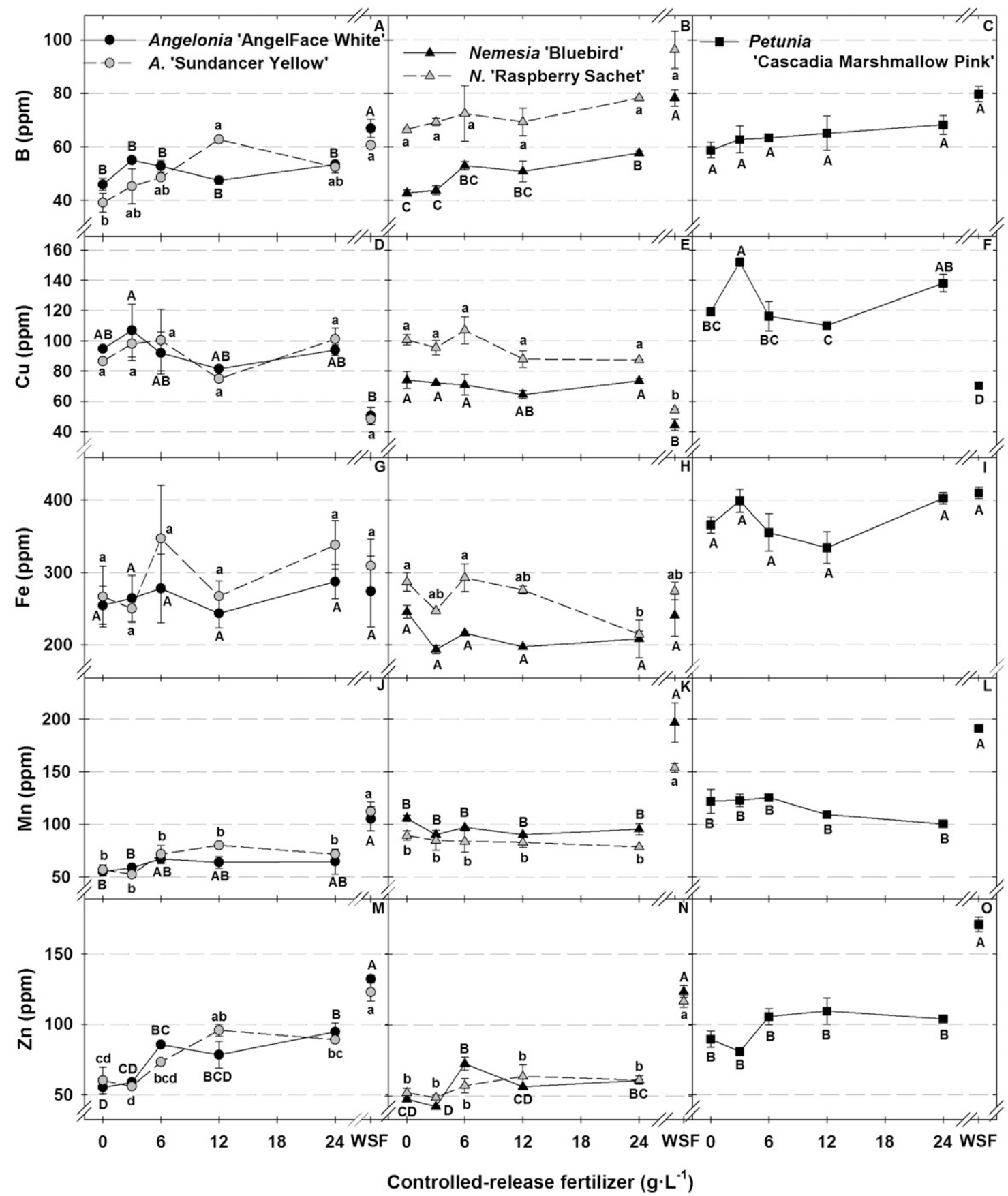

Fig. 5. Tissue boron (B), copper (Cu), iron (Fe), manganese (Mn), and zinc ( $\mathrm{Zn})$ concentrations of Angelonia 'AngelFace White' and 'Sundancer Pink' angelonia, Nemesia 'Bluebird and Raspberry Sachet', and Petunia 'Cascadia Marshmallow pink' shoot tissue $28 \mathrm{~d}$ after inserting cuttings into substrate containing $0,3,6$, 12 , or $24 \mathrm{~g}$ controlled-release fertilizer (CRF) per liter or provided water-soluble fertilizer (WSF) during propagation. Each symbol represents the mean of two 14-cell propagation strips, and error bars represent SES of the mean. Different letters are significantly different by Tukey's honestly significant difference (HSD) test at $P \leq 0.05$ within each cultivar.

Hot', Nemesia 'Raspberry Sachet', and Petunia 'Cascadia Marshmallow Pink' was unaffected by fertilizers. Although WSF did not affect tissue $\mathrm{Cu}$ concentrations of both Angelonia cultivars and Petunia 'Suncatcher Yellow', $\mathrm{Cu}$ levels in other taxa fertilized with WSF were $40 \%$ (29.8 ppm, Nemesia 'Bluebird') to $64 \%$ (156.6 ppm, Impatiens 'Celebrette Apricot') lower compared with unfertilized cuttings; CRF had minimal impact on $\mathrm{Cu}$ concentrations. Although fertilizers had little effect on tissue Fe for most species, increasing CRF from 0 to $24 \mathrm{~g} \cdot \mathrm{L}^{-1}$ led to reduced Fe of Nemesia 'Raspberry Sorbet' by $25 \%$ (72.2 ppm). Similarly, although CRF minimally affected tissue Mn of most species, WSF elevated Mn by $42 \%$ (49.7 ppm, Impatiens 'Celebrette Rose Hot') to $97 \%$ (55.3 ppm, Angelonia Sundancer Pink') compared with unfertilized cuttings. Although tissue Zn for Petunia 'Suncatcher Yellow' was unaffected by fertilizers, WSF increased $\mathrm{Zn}$ by 37\% (30.2 ppm; Impatiens 'Celebrette Rose Hot') to $159 \%$ (75.8 ppm, Nemesia 'Bluebird') compared with unfertilized cuttings. Fertilizers had no effect on Mo for each species (data not shown). Although not quantified, the use of tap water in our study may have contributed some mineral nutrients to the mist solution and, therefore, to plant tissue concentrations.

\section{Discussion}

We have only found one report on the use of CRFs during vegetative propagation of herbaceous perennial ornamental plants (Rowe and Cregg, 2002). However, to evaluate the effectiveness of using CRFs in propagation of 


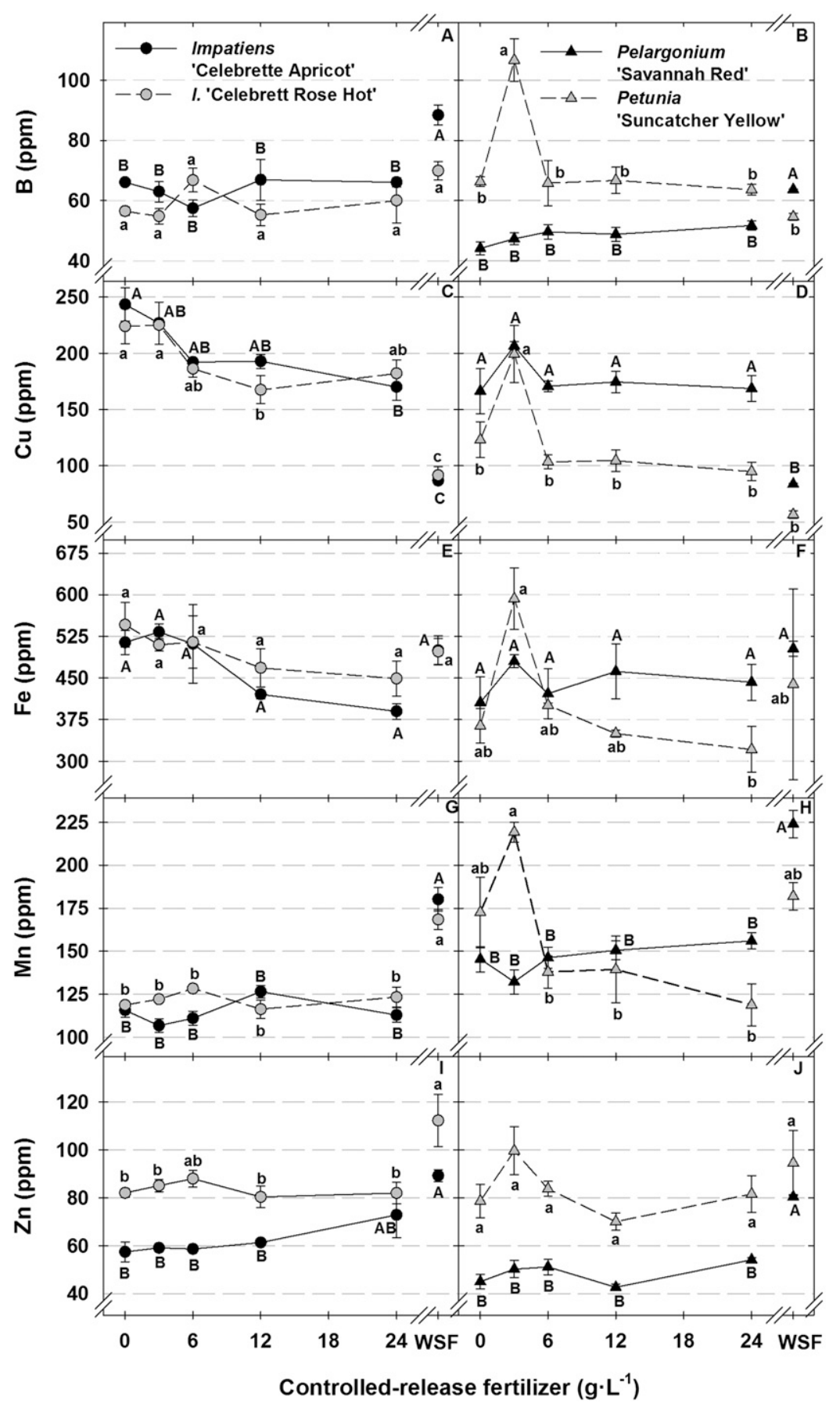

Fig. 6. Tissue boron (B), copper $(\mathrm{Cu})$, iron $(\mathrm{Fe})$, manganese $(\mathrm{Mn})$, and zinc $(\mathrm{Zn})$ concentrations of Impatiens hawkeri 'Celebrette Apricot' and 'Celebrette Rose Hot', Pelargonium Xhortorum 'Savannah Red', and Petunia $\times$ hybrida 'Suncatcher Yellow' shoot tissue $28 \mathrm{~d}$ after inserting cuttings into substrate containing $0,3,6,12$, or $24 \mathrm{~g}$ controlled-release fertilizer (CRF) per liter or provided water-soluble fertilizer (WSF) during propagation. Each symbol represents the mean of three 14-cell propagation strips, and error bars represent SES of the mean. Different letters are significantly different by Tukey's honestly significant difference (HSD) test at $P \leq 0.05$ within each cultivar.

annual bedding plant species, we need to evaluate the impact on growth, morphology, and tissue nutrient levels. Shoot growth, including stem length and caliper and SDM, was generally enhanced with the application of CRF or WSF. Although we have found no data on the response of stem caliper or length of cuttings to fertilization during propagation, previous studies have reported an increase in SDM and stem length with fertilization (Rowe and Cregg, 2002; Santos et al., 2011b). Rowe
7 to $21 \mathrm{~d}$. Producers could inhibit any excessive stem length resulting from CRFs by applying plant growth retardants or by shearing cuttings. Shearing may yield additional benefits such as increasing the R:S ratio and/ or the sturdiness of rooted cuttings as measure by the sturdiness quotient (stem caliper/ stem length; Currey et al., 2012).

A primary goal during cutting propagation is to produce fully rooted ("pullable") cuttings (Lopez and Runkle, 2008). Therefore, our data on the impact of CRF and WSF fertilization on RDM of cuttings is of special interest with reference to efficient propagation of cuttings. For several species, RDM decreased with CRF or WSF application. However, data from other studies demonstrate variation in the response of herbaceous cuttings impact of CRF or WSF during propagation on RDM. Rowe and Cregg (2002) reported that although increasing $\mathrm{N}$ from CRF from 0 to $2.13 \mathrm{~g} \cdot \mathrm{L}^{-1}$ increased RDM of Gaura, RDM of Artemesia and Nepeta was unaffected by CRF. Alternatively, Santos et al. (2011b) reported that, compared with cuttings receiving only micronutrients, RDM of Petunia cuttings decreased as the number of days cuttings received mist containing macronutrients from WSF increased from 7 to $21 \mathrm{~d}$. However, in another study, Santos et al. (2009) reported that RDM of Petunia 'Supertunia Royal Velvet' and 'Supertunia Priscilla' increased by $1021 \%$ and $143 \%$, respectively, when clear water supplemented with WSF was applied to the basal end of cuttings during propagation.

Although RDM decreased with fertilization, all cuttings were fully rooted and considered "pullable" at the end of the 4-week propagation period (data not shown). Furthermore, Lopez and Runkle (2008) reported that Petunia 'Tiny Tunia Violet Ice' and Impatiens 'Harmony White' cuttings were considered fully rooted when RDM was $10 \mathrm{mg}$ or greater and $30 \mathrm{mg}$, respectively. In our study, RDM of both Impatiens and Petunia cultivars cuttings exceeded the value for Lopez and Runkle (2008) reported for as necessary for fully rooted Impatiens and Petunia cuttings propagated in cells with a similar individual cell volume. Alternatively, we did not find other published guidelines for RDM for fully rooted cuttings of other taxa. However, we feel that when our observations on the pullability of rooted cuttings across taxa and fertilizer treatments in this study are taken together, the impact of CRF treatments on RDM does not preclude their use during cutting propagation.

Replenishing macro- and micronutrients tissue concentrations is another goal of fertilization during propagation. On arrival and receipt in the United States, cuttings originating from off-shore stock plant facilities generally have adequate tissue concentrations of mineral nutrient concentrations within recommended ranges (Santos et al., 2011a). However, although uptake and tissue content of nutrients including $\mathrm{N}, \mathrm{P}$, and $\mathrm{K}$ may increase throughout propagation, tissue nutrient concentrations of fertilized cuttings decline (Blazich, 1988; Santos et al., 2009, 2011b; 
Svenson and Davies, 1995). Nutrient concentrations of shoot tissue were compared with species-specific published recommended sufficiency ranges for mineral nutrient concentrations to better evaluate the suitability of CRF for use in propagation (Gibson et al., 2007; Mills and Jones, 1996). Although there were some exceptions, cuttings propagated in substrates containing $6 \mathrm{~g} \cdot \mathrm{L}^{-1}$ generally had tissue concentrations within the sufficiency ranges for established plants in the finishing phase of production.

When growth and morphology data (Figs. 1 and 2) are taken together with tissue nutrient concentrations (Figs. 3 to 6), it is difficult to justify the use of CRF above $6 \mathrm{~g} \cdot \mathrm{L}^{-1}$. The use of 12 or $24 \mathrm{~g} \cdot \mathrm{L}^{-1} \mathrm{CRF}$ may be useful if producers aim for a "nutrient loading" effect for subsequent growth after transplanting. However, there were few statistical differences in growth, morphology, or nutrient concentrations for cuttings propagated in 12 or $24 \mathrm{~g} \cdot \mathrm{L}^{-1}$ CRF compared with cuttings propagated in $6 \mathrm{~g} \cdot \mathrm{L}^{-1}$. Furthermore, regression analyses suggest that increasing CRF above the rates used in this study would not further enhance tissue $\mathrm{N}$ levels. When the short duration of propagation is taken together with the decline in tissue nutrient concentrations and initial absence and subsequent development of roots, maintaining and/or restoring tissue nutrient concentrations to published sufficient ranges may be difficult to achieve. Alternatively, these ranges may not be appropriate for this crop stage, i.e., recently rooted cuttings. Because cuttings fertilized with greater amounts of CRF generally had statistically similar tissue concentrations as those fertilized with WSF, $6 \mathrm{~g} \cdot \mathrm{L}^{-1} \mathrm{CRF}$ appears to be a viable alternative for use in cutting propagation for a number of species.

Producers must consider several additional factors when evaluating CRFs for use in propagation. First, although our results suggest incorporating up to $24 \mathrm{~g}$ of $\mathrm{CRF} / \mathrm{L}$ of substrate, the volume of substrate required per unit area for propagation trays is much less than the amount of substrate required to for an equivalent area of flats, containers, or hanging baskets. Furthermore, although incorporating large amounts of CRF into substrate may initially induce "sticker shock," the cost of providing CRF during propagation must be considered relative to the value of the tray of rooted cuttings. Using an average wholesale price for the cost of the CRF used in our experiment, it would cost $\approx \$ 0.30$ per tray of cuttings to provide $24 \mathrm{~g} \cdot \mathrm{L}^{-1}$, a tray of rooted cuttings may cost from $\$ 65$ to $\$ 75$ (A. Pyle, personal communication). Additionally, CRF may add value for producers who must hold rooted cuttings, if planting is delayed, or as an additional source of nutrients during finishing.

\section{Conclusions}

CRFs generally increased tissue levels of macronutrients for most species in this study and, at the highest rates, were comparable to cuttings receiving WSF with respect to growth and morphology and tissue nutrient concentration. Specifically, incorporating 6 to $12 \mathrm{~g} \cdot \mathrm{L}^{-1} \mathrm{CRF}$ results in shoot tissue nutrient concentrations similar to cuttings propagated using WSF, yet minimizes some of the excessive growth associated with the highest rate of CRF. More research identifying the effect of substrate temperature and prill size and release pattern would assist in developing best management practices for the use of CRF in cutting propagation of herbaceous taxa.

\section{Literature Cited}

Blazich, F.A. 1988. Mineral nutrition and adventitious rooting, p. 61-69. In: Davis, T.D., B.E. Hassig, and N. Sankhla (eds.). Adventitious root formation in cuttings. Dioscorides Press, Portland, OR.

Currey, C.J., V.A. Hutchinson, and R.G. Lopez. 2012. Growth, morphology, and quality of rooted cuttings of several herbaceous annual bedding plants are influenced by photosynthetic daily light integral during root development. HortScience 47:25-30.
Gibson, J.L., D.S. Pitchay, A.L. Williams-Rhodes, B.E. Whipker, P.V. Nelson, and J.M. Dole. 2007. Nutrient deficiencies in bedding plants: A pictorial guide for identification and correction. Ball Publishing, Batavia, IL.

Lopez, R.G. and E.S. Runkle. 2008. Photosynthetic daily light integral during propagation influences rooting and growth of cuttings and subsequent development of New Guinea impatiens and petunia. HortScience 43:20522059.

Mills, H.A. and J.B. Jones, Jr. 1996. Plant analysis handbook. II: A practical sampling, preparation, analysis, and interpretation guide. MicroMacro Publishing, Athens, GA.

Nelson, P.V. 2012. Greenhouse operations and management. 7th Ed. Prentice Hall, Upper Saddle River, NJ.

Rowe, D.B. and B.M. Cregg. 2002. Effect of incorporating controlled-release fertilizer on adventitious rooting and growth of Artemesia, Gaura, and Nepeta. J. Environ. Hort. 20:1-6.

Santos, K.M., P.R. Fisher, and W.R. Argo. 2008. A survey of water and fertilizer management during cutting propagation. HortTechnology 18:597604 .

Santos, K.M., P.R. Fisher, and W.R. Argo. 2009. Stem versus foliar uptake during propagation of Petunia Xhybrida vegetative cuttings. HortScience 44:1974-1977.

Santos, K.M., P.R. Fisher, and W.R. Argo. 2011a. Survey of tissue nutrient levels in vegetative cuttings. Commun. Soil Sci. Plant Anal. 42: 669-693.

Santos, K.M., P.R. Fisher, T. Yeager, E.H. Simonne, H.S. Carter, and W.R. Argo. 2011b. Soil management, fertilization, and irrigation timing of macronutrient supply during cutting propagation of Petunia. HortScience 46:475480.

Sonneveld, C. and W. Voogt. 2009. Plant nutrition of greenhouse crops. Springer, Dordrecht, The Netherlands.

Svenson, S.E. and F.T. Davies, Jr. 1995. Change in tissue mineral elemental concentration during root initiation and development of poinsettia cuttings. HortScience 30:617-619.

U.S. Department of Agriculture. 2012. Floriculture crops 2011 summary. Nat. Agr. Sta. Service, Washington, DC. 30 Oct. 2012. <http://usda01. library.cornell.edu/usda/current/FlorCrop/ FlorCrop-05-31-2012.pdf>. 